\title{
The CASE For AND Against MANDATORY GENDER QUOTA LEGISLATION FOR COMPANY BOARDS
}

\author{
Jean du Plessis*
}

\section{INTRODUCTION AND OVERVIEW}

This special issue of the Deakin Law Review contains articles based on papers delivered at the forum - 'Mandatory Gender Quota Legislation: Will Australia follow Europe?' - held in Melbourne on 20 October 2014. ${ }^{1}$ It was the second forum sponsored by the Deakin Law School as well as the German Alexander von Humboldt Foundation ${ }^{2}$ and the German Federal Ministry of Education and Research through the Anneliese Maier Research Award. ${ }^{3}$

The Inaugural International Corporate Governance and Law (ICGL) Forum was held in Münster on 4-5 November 2013. ${ }^{4}$ Its theme was intentionally very broad, namely 'Key Corporate Governance Themes and Issues in a Globalised and Internationalised World', in order to identify as many core international corporate governance and corporate law themes and issues as possible. The

\footnotetext{
* Professor of Law, Deakin University (Australia).

1 ‘Mandatory Gender Quota Legislation: Will Australia Follow Europe?’ International Corporate Governance and Law <http://2014.icgl.org.au/>.

${ }^{2}$ Alexander von Humboldt Foundation <http://www.humboldt-foundation.de/web/home.html>.

${ }^{3}$ See <http://www.humboldt-foundation.de/web/anneliese-maier-award.html $>$. This award of $€ 250000$ over a five year period (2013-2017), was awarded to Professor Jean du Plessis based on a nomination by Professor Ingo Saenger, University of Münster. It was one of seven Anneliese Maier Research Awards made by the Alexander von Humboldt Foundation in 2013. The award winners were selected from the 54 people (from 26 different countries) nominated for the Award in 2012. Nominations were invited from all disciplines of the humanities and social sciences, but not natural sciences. The nominations were all aimed at the further internationalisation of the humanities and social sciences in Germany. The Award is dedicated to the further internationalisation of German corporate governance and corporate law.

${ }^{4}$ See International Corporate Governance and Law Forum <http://2013.icgl.org.au/>.
} 
papers delivered at the 2013 Forum were published in a special issue of the European Business Law Review. ${ }^{5}$

\section{Significance of the ForUm THEME AND THE 'PURPOSE OF THE CORPORATION'}

The theme for the 2014 Forum was, on the other hand, very narrow and very focused: 'Mandatory Gender Quota Legislation: Will Australia Follow Europe?'. This theme was selected because gender equality is emerging as a significant debate in Australian corporate governance, and because of significant developments in the European Union, and especially in Germany at the end of 2013 and early in 2014. It was also selected because it is one of the areas identified as part of the 5-year Anneliese Maier Research Project ${ }^{6}$ and because it is predicted that the topic of gender quota legislation will become more significant in the future.

It took a long time for 'gender diversity' to be seen not only as a social justice, equity or political issue, but also as a core corporate governance issue. In the past it was hardly mentioned in corporate governance books. However if 'board diversity' is an important issue, promoted through almost every single modern corporate governance code, and 'gender diversity' is the dominant 'board diversity' issue, one must concede that 'board gender diversity' is nowadays an important corporate governance issue.

Gender quota legislation is an area that will also become more and more prominent for the purposes of comparative academic research. Such comparative research should focus, on the one hand, on the particular legal instruments used in different countries to enforce gender quotas. The differences in sanctions and how they have impacted on the achievement of the required quotas should also be compared over time. On the other hand, the vexed issue of board diversity, and gender diversity as part of the broader theme of board diversity, will become even more prominent as more countries adopt mandatory gender quota legislation. An area of particular interest in future will remain what the impact of board diversity generally is on fulfilling 'the purpose of the corporation'. In studies of that broader area, the focus will also be on what impact a much larger percentage of women on boards will have on 'the purpose of the corporation' and on fulfilling this purpose.

\footnotetext{
${ }^{5}$ (2015) 26 EBLR 1-243.

${ }^{6}$ See $<$ http://www.icgl.org.au/vision/>.
} 
The question that has so far been asked is whether there is a 'business case' to be made for having more women on boards. That question was dominated for several years by what was seen as the primary, and even exclusive, purpose of for-profit corporations, namely 'profit maximisation'. Profit maximisation for whom? For the company, but 'the company' defined as 'current and future shareholders'. This resulted in the 'shareholder primacy' theory of company law. However, several other theories, such as the 'enlightened shareholder theory' and the 'stakeholder theory' have become more and more prominent in recent times. There are also more and more voices challenging the proposition that the primary or exclusive purpose of a company is 'profit maximisation' ${ }^{7}$ It is almost indisputable that we have moved away from the view that the primary aim of corporations is 'to make profit' or 'to make money'. ${ }^{8}$ The current reality is that there is a very widely held view that companies should do business in a responsible way and aim at sustainable value creation. Corporations cannot any longer hide behind the 'profit maximisation purpose of the corporation' to deny that they also have a prominent responsibility to act for the public good. ${ }^{9}$ This means that the boards of directors should also focus on environmental matters, social and employee-related matters, human rights, and anti-corruption and bribery issues, among others.

There is a very strong drive internationally for corporations to demonstrate that they are not only focused on profit-maximisation, but also on these other matters and issues. This drive is clearly noticeable in the different forms of reporting expected - Corporate Social Responsibility Reporting; Corporate Responsibility Reporting; Integrated Reporting; and Sustainability Reporting ${ }^{10}$ - although not yet reflected in legislation. Thus, to ask the question whether there is a business case for having more women on boards is no longer the only relevant question. The question nowadays and for the foreseeable future will be: 'Is there a case for having more women on boards to ensure that companies fulfil their wider responsibilities?’ In her article Professor Beate Sjåfjell

\footnotetext{
7 See in particular <http://themoderncorporation.wordpress.com/company-law-memo/>; $<$ http://themoderncorporation.wordpress.com/>; and <http://www.purposeofcorporation.org/ cs>. In 2013 The Corporate Governance Institute of Australia started with a project focusing on the 'shareholder primacy theory. See Governance Institute of Australia, Shareholder Primacy: Is There a Need for Change?, Discussion Paper (2014) <http://www. governanceinstitute.com.au/media/695936/govinst_shareholder_primacy_disc_paper_october 2014_web.pdf>.

${ }^{8}$ See Jean J du Plessis and Andreas Rühmkorf, 'New Trends Regarding Sustainability and Integrated Reporting for Companies: What Protection Do Directors Have?' (2015) 36 The Company Lawyer 49, 52.

${ }^{9}$ Ibid.

${ }^{10}$ Ibid 52-4.
} 
addresses this issue by asking the question: 'Does gender diversity contribute to sustainability?'.

The answer to that is not an easy one. Not only is it complex to determine how sustainability should be measured, but the complexities increase exponentially if the question is asked to what extent gender diversity, or an increase in the number of women on boards, has contributed to such sustainability. Another problem is, of course, that of comparing data. Even if the proper means of measuring sustainability could be determined with greater precision, such means are not available for use because they were not used in the past when men dominated boards. Older data can, therefore, not be compared with data from the present when women make up, say, 30-40 per cent of boards of all listed companies. At least for the moment, one will have to generalise and say that it is highly likely that more women on boards will have an impact on sustainability. One thing is certain, however. Because of the current wider view of the purpose of the corporation, the argument that there is no conclusive 'business case' for having more women on boards no longer holds water. It is no longer persuasive as an argument for why more women should not be appointed to boards or, more specifically, as an argument against gender quota legislation.

To get back to the Forum theme, the word 'mandatory' was added because of an important distinction between different types of gender quota legislation. Under a model of 'mandatory gender quotas' the legislation dictates the quota (30-40 per cent) for each gender, with serious consequences (in Norway dissolution of the company) if the quota is not reached and maintained. As is explained in the article by Professor Beate Sjåfjell, Norway was the first country to adopt such legislation ('hard law').

In the Netherlands there is also legislation that stipulates targets or quotas (30 per cent) for each gender, but there are no sanctions if these quotas are not reached or maintained, as explained in the article by Professor Mijntje Lückerath-Rovers. Thus, in the case of the Netherlands, it is appropriate to refer only to 'gender target legislation' as the targets are set in legislation, but they are only targets and not mandatory quotas - the 'soft law' approach. As Professor Lückerath-Rovers argues, the 'comply or explain' principle applies and a company not having reached the target must explain several things.

In several other jurisdictions there is no legislation dealing with gender quotas. Quotas or targets are simply mentioned generally as an option, or they are set or mentioned in voluntary corporate governance codes. In that case companies will, under the principle of 'comply or explain' that is adopted in most 
voluntary corporate governance codes, simply have to explain if the quotas are not met - again the 'soft law' approach.

The articles in this special issue of the Deakin Law Review deal with almost all the arguments for and against legislation for mandatory gender quotas. The issue deals in detail with legislation already in place in Norway, the Netherlands and Germany (where, however, quotas of 30 per cent of each gender do not need to be reached until 2016).

\section{GRADUAL RECOGNITION OF THE IMPORTANCE OF BOARD DIVERSITY AND BOARD GENDER DIVERSITY}

The various methods of achieving board gender diversity are touched upon by most of the articles. In the past, it was simply argued that board composition was a matter for the company to decide and that there should not be any form of interference with that process. However, with the rise of the important role of non-executive directors, in particular independent non-executive directors, corporate governance codes started to require listed companies to explain, under the 'comply or explain' principle, certain aspects of their board composition if it did not meet the expectations of the relevant code. These aspects included, for instance, whether the CEO was also the Chair of the Board, why there were not a majority of independent non-executives serving on the board, and whether some board committees were not chaired by, or composed of, a minimum number of independent non-executive directors. Thus, the approach was a soft-law approach.

The importance of board diversity generally was only emphasised in corporate governance codes at a later stage. As an aspect of board diversity, the issue of gender diversity on boards started to creep in. There is no doubt that the debate about board gender diversity received considerably more attention after Norway introduced mandatory board gender quotas, but only a few countries followed the method of quota legislation. However, the debate on board gender diversity escalated and those responsible for corporate governance codes could not avoid bringing the issue of board gender diversity into the codes. How it was introduced varies from country to country. Three interesting examples are found in the 2014 UK Corporate Governance Code, the 2014 ASX Corporate Governance Principles and Recommendations and the 2014 German Corporate Governance Code, none of which sets targets or quotas, but each of which requires disclosure of diversity policy, including board gender diversity. 
Principle B.2.4 of the 2014 UK Corporate Governance Code provides as follows:

A separate section of the annual report should describe the work of the nomination committee, including the process it has used in relation to board appointments. This section should include a description of the board's policy on diversity, including gender, any measurable objectives that it has set for implementing the policy, and progress on achieving the objectives. ${ }^{11}$

Recommendation 3.2: of the 2014 ASX Corporate Governance Principles and Recommendations provides as follows:

Companies should establish a policy concerning diversity and disclose the policy or a summary of that policy. The policy should include requirements for the board to establish measurable objectives for achieving gender diversity and for the board to assess annually both the objectives and progress in achieving them. ${ }^{12}$

Recommendation 3.4 of the 2014 ASX Corporate Governance Principles and Recommendations provides as follows:

Companies should disclose in each annual report the proportion of women employees in the whole organisation, women in senior executive positions and women on the board. ${ }^{13}$

Clause 4.1.5 of the German Corporate Governance Code (GCGC) provides as follows:

When filling managerial positions in the enterprise the Management Board shall take diversity into consideration and, in particular, aim for an appropriate consideration of women. ${ }^{14}$

Clause 5.1.2 of the 2014 German Corporate Governance Code (GCGC) provides as follows:

\footnotetext{
${ }^{11}$ Financial Reporting Council, UK Corporate Governance Code, <https://www.frc.org.uk/OurWork/Codes-Standards/Corporate-governance/UK-Corporate-Governance-Code.aspx>.

12 Australian Securities Exchange Corporate Governance Council, 'Corporate Governance Principles and Recommendations $3^{\text {rd }}$ edition' (Report, ASX Corporate Governance Council, March 2014).

${ }^{13}$ Ibid.

14 Regierungskommission Deutscher Corporate Governance Kodex, German Corporate Governance Code (5 May 2015) <http://www.dcgk.de/de/kodex.html>.
} 
The Supervisory Board appoints and dismisses the members of the Management Board. When appointing the Management Board, the Supervisory Board shall also respect diversity and, in particular, aim for an appropriate consideration of women. ${ }^{15}$

It should be noted that because of the recently adopted legislation (in March 2015) on gender quotas in Germany ${ }^{16}$ the GCGC will probably be amended soon to reflect the new statutory approach to gender diversity. However, if one looks at all the approaches in the above quoted corporate governance codes, it is clear that they use a 'soft law' approach to gender diversity, with no quotas or targets dictated, although explanations will have to be provided if there is a deviation from the required Code standard. For instance, companies falling under the 2014 UK Code will have to explain ('comply or explain' principle) if they do not have, as a separate section of the annual report, a section dealing with 'a description of the board's policy on diversity, including gender, any measurable objectives that it has set for implementing the policy, and progress on achieving the objectives'. ${ }^{17}$ Similarly, companies falling under the 2014 ASX Code will have to explain if they do not have 'a policy concerning diversity' or have not disclosed 'the policy or a summary of that policy'. ${ }^{18}$ In addition, they will have to explain if, in that policy, there is not a part dealing with 'measurable objectives for achieving gender diversity and for the board to assess annually both the objectives and progress in achieving them' ${ }^{19}$ What the policy is, and what the measurable objectives are and how they are assessed annually, are all up to the company - no gender targets or quotas are directed. Although the 2014 GCGC is much vaguer, companies falling under it will have to explain if they have not taken gender into consideration in their appointments. However, it is highly unlikely that any board will admit to not having complied with this expectation.

\section{INTERNATIONAL IMPACT OF THE NORWEGIAN LEGISLATION}

Since the adoption of mandatory gender quota legislation by Norway, several other countries, including Belgium, France, Italy and Spain, have adopted

\footnotetext{
${ }^{15}$ Ibid.

${ }^{16}$ See Raphael Koch, 'Board Gender Quotas in Germany and the EU: An Appropriate Way of Equalising the Participation of Women and Men?' (2015) 20(1) Deakin Law Review 53, 5960.

${ }^{17}$ Financial Reporting Council, above n 11.

${ }^{18}$ ASX, above n 12.

${ }^{19}$ Ibid.
} 
comparable legislation. There are variations in the mandated percentage of women board members among these countries and also significant variations regarding the sanctions imposed if those quotas are not met.

On 20 November 2013 the European Parliament voted, by a large majority, in favour of a directive aimed at getting at least 40 per cent females and 40 per cent males appointed to the boards of larger companies. However, the directive was road-blocked when the European Council announced that it could not reach agreement on its final adoption. As there is still slight hope that progress will be made in future it is worth quoting the summary of the outcome on the issue of 'women on boards', specifically noting the comments about what is in the best interests of EU economies:

The Council discussed the women on company boards directive. It was not able to reach a general approach. Minister Poletti said: 'Enhancing women’s participation in economic decision-making is essential to promote equality between women and men in our societies and would be beneficial to our economies. We have been working hard during these six months to unlock negotiations on the proposed directive for improving the gender balance on company boards and we are now closer to an agreement. Building on our progress I am confident that the Council will be able to move forward with this important dossier. ${ }^{20}$

It is noteworthy that, if the Directive had been adopted in the form approved by the European Parliament and considered by the European Council, EU member states would have been expected to implement measures to achieve the aim of getting at least 40 per cent females and 40 per cent males appointed to the boards of larger companies. It is important, however, that there is flexibility regarding the legal instruments that EU members could use to implement directives. Some countries, such as Germany, have already opted for mandatory gender quota legislation - the 'hard law' approach. Other countries would probably use voluntary corporate governance codes to reach these quotas - the 'soft law' approach. Some countries will probably continue only to expect of companies that they explain if these quotas are not reached. It will then be left to the market to respond to companies which have not reached the quotas and have not explained why not. The response of the market basically means the investors' (primarily shareholders') response to the lower-than-expected

\footnotetext{
${ }^{20}$ Press release from the 3357th European Council meeting, Employment, Social Policy, Health and Consumer Affairs, Brussels, 11 December 2014, 9-10, available at <http://www. consilium.europa.eu/uedocs/cms_data/docs/pressdata/en/lsa/146172.pdf>.
} 
percentage of women on a particular company's board and to the explanations provided by that company: Will investors put pressure on boards to reach the quotas? Will there be expectations in the market that large institutional investors should only invest in companies where 40 per cent of the board members are women? All of this is now speculation only because of the fact that the European Council could not agree on a general approach.

\section{IMPORTANCE OF BOARD DIVERSITY}

The importance of board diversity was generally accepted by all the presenters at the Forum. Professor Michael Adams's article emphasises most clearly that the issue of board diversity is much wider than just gender diversity, observing that race, with cultural heritage (expressed as 'ethnicity'), education, professional background and age are also important for the purposes of board diversity. The reasons why diversity is considered important vary. Some argue that one important reason is that it prevents 'group-think'. Implied in this is the assumption that a diverse board would make more balanced decisions and that a diverse board improves decision making processes - as has been shown by 'behavioral economics'. ${ }^{21}$ Professor Adams quotes from a 2013 Report by the Korn Ferry Institute to illustrate the point:

By ensuring sufficient diversity, high-performing boards can be assured that board decisions will be vigorously debated by individuals with different perspectives leading to improved board monitoring, better board meeting attendance rates, and causes boards [sic] to be more stakeholder focused boosting shareholder value and representing customers, employees, and business partners... A diverse group of directors is more likely to raise questions, challenge the status quo, or spot new opportunities. Appointing directors from different ethnic, age and educational backgrounds can immediately add multiple perspectives to the oversight lens. ${ }^{22}$

However, he also points out that there is a deep divide as to what method should be used to achieve board diversity generally and gender diversity in particular.

\footnotetext{
${ }^{21}$ See generally Kent Greenfield, 'Sticking the Landing: Making the Most of the "Stakeholder Moment” ' (2015) 26 EBLR 147, 154-5.

${ }^{22}$ Michael Adams, 'Board Diversity: More Than a Gender Issue?' (2015) 20(1) Deakin Law Review 123.
} 


\section{SELECTEd JURISDictions}

\section{A Norway: First Country out of the Blocks with Mandatory Gender Quota Legislation}

Professor Beate Sjåfjell, focusing on Norway, approaches the topic of board diversity and gender diversity from a corporate governance perspective rather than a gender equality one. Her overview of how the Norwegian legislation came about is interesting as it illustrates that if companies, through internal initiatives or with the encouragement of director-orientated organisations, had increased the percentage of women more significantly from 2003 to 2005, the legislation forcing companies to appoint at least 40 per cent women to their boards would not have become law. The legislation, with its drastic sanction of dissolution of companies not having reached the quotas, ${ }^{23}$ had a significant impact and, by 7 January 2008, 90 per cent of the public companies required to comply with the legislation had reached the 40 per cent gender quota. It was only a few months later that all companies complied. Professor Sjåfjell points out that the legislation had considerable impact not only in Norway, but also internationally. An interesting trend was observed in Norway: at the same time as the legislation was passed and the date (1 January 2008) approached, several Norwegian public companies converted to private companies. Some commentators made the claim that this trend was directly related to the mandatory gender quota legislation. However, Professor Sjåfjell refers to studies that have shown that only a very small number of these conversions could be directly attributed to the mandatory gender quota legislation.

One part of Professor Sjåfjell's article is dedicated to the positive effects of having more women on boards. They include the different perspectives and attitudes that women bring to the board and the breaking of 'group-think'. However, she is realistic in her approach, pointing out that in order to establish a proper business case for appointing more women to boards, it is necessary to distinguish between studies of the effect of gender diversity: first, on the value creation in the company; second, on the profits as measured by the accounts; and third, on dividends to shareholders.

Professor Sjåfjell defends the drastic sanction of dissolution if the required quotas are not met or maintained. She explains that the sanction of 'dissolution'

\footnotetext{
${ }^{23}$ Professor Sjåfjell points out that the dissolution will not be of immediate effect if the quota is not reached or maintained. It will be proceeded with after several warnings and opportunities for the company to put together a legal board, consisting of the required 40 per cent for each gender: Beate Sjåfjell, 'Gender Diversity in the Boardroom and Its Impacts: Is the Example of Norway a Way Forward?’ (2015) 20(1) Deakin Law Review 25, 32.
} 
was considered by some to be 'disproportionate', but disagrees with this proposition:

[T]he preparatory works emphasise that dissolution is the most effective sanction, and thus also the most appropriate. The sanction is, from a Norwegian company law perspective, completely in line with that which applies when other fundamental requirements are breached, including the requirements of sending in accounts according to the Accounting Act and of having an auditor. As opposed to much CSR (Corporate Social Responsibility) regulation, which either does not have teeth to start with or is not enforced, the Norwegian mandatory gender quota rule is dealt with as core company law should be - seriously. This in itself is also indicative of the aim: better corporate governance, as opposed to reporting requirements on gender diversity as CSR regulation. ${ }^{24}$

She draws the following general conclusions:

Based on the general indications that female directors take broader and longer-term perspectives discussed in this section, as well as the general positive impact of breaking up group-think indicated in this article, we may envisage that gender diversity on corporate boards is a small but positive contribution to the necessary transition away from business as usual and onto a sustainable path. ${ }^{25}$

Her concluding sentences clearly reminds us of the bigger picture:

Lest we end up fiddling while the world burns, we need to keep our eyes on the overarching goal of long-term sustainability, financial and social, within the planetary boundaries. At the end of the day, that and nothing else is the benchmark against which we should be measured. ${ }^{26}$

\section{B Germany: Adopted Mandatory Gender Board Legislation, but Opposition and Challenges to Be Expected}

Professor Raphael Koch's article deals with recent developments regarding board diversity and gender diversity in Germany and in the EU. He is not convinced that mandatory gender quotas are the right way to go. Although they seem to be a fait accompli, Professor Koch discusses possible opposition to gender quotas and the challenges the legislation may encounter in Germany as

\footnotetext{
24 Ibid 33.

${ }^{25}$ Ibid 49.

${ }^{26}$ Ibid 51.
} 
well as in the EU if it is adopted. He explains that there are very convincing constitutional objections that could be raised against mandatory gender quota legislation. He also points out that '[i]t remains to be seen whether quotas on women can fulfil the expectations held of them' ${ }^{27}$ He points to the fact that mandatory gender quota legislation will increase the proportion of women on supervisory boards in Germany. He also takes it as a given that, with more women serving on supervisory boards in Germany, a new, independent professional profile will be established in the future, which would promote the professionalisation of supervisory boards. However, he is sceptical whether quotas on women will improve the professional promotion of women at levels other than at supervisory board level. He uses Norway as an example:

A recent study there found that, despite the introduction of a quota on women in 2003, the proportion of women in middle management positions has remained unchanged, and has only increased on the highest management level. The wage gap between men and women has not changed significantly either; in other words, the quota on women has not yet led to an integral change in working conditions for women. ${ }^{28}$

Based on this, he argues that female advancement must be approached from many sides. Limiting this solely to an increase in the proportion of women on supervisory boards is not sufficient. Changes must be made on other levels as well. He explains:

Today, the question of whether women pursue a professional career increasingly depends on the compatibility between family and a career. This can be seen in Sweden and Denmark, where - as previously discussed there are still no statutory quotas. In spite of this, the proportion of women on supervisory boards is well over 20 per cent there. It is true that female advancement is on the political agenda. However, it is questionable whether company law should be used as an important vehicle to achieve it. ${ }^{29}$

He concludes by providing some final perspectives:

On the one hand, quotas on women are a foreign body in company law; on the other hand, they are insufficient. For professional advancement, there must be, if nothing else, comprehensive family-related political reforms and improvements - regardless of gender! ${ }^{30}$

\footnotetext{
${ }^{27}$ Koch, above n 16, 73.

${ }^{28}$ Ibid 73.

${ }^{29}$ Ibid 73-4.

${ }^{30}$ Ibid 74.
} 


\section{The Netherlands: An Experiment with Targets in Legislation, but not Mandatory Quotas}

Professor Mijntje Lückerath-Rovers commences her article by giving an overview of the history of the current Dutch system. In the Netherlands, as in Germany, all public companies must have two boards, namely the supervisory board and the management board. From 1 January 2013 companies were also given the opportunity to adopt a unitary board system. In January 2013 it also became law that Dutch companies falling under the legislation must explain three things if at least 30 per cent of either their supervisory board or management board are not of the same gender. This 30 per cent target is to be met by 1 January 2016, and that is also the day on which the legislation will automatically be repealed. In other words the legislation contains a sunset clause. Professor Lückerath-Rovers illustrates that it had already become apparent in September 2014 that the targets would not be met and this again intensified the debate on mandatory gender quota legislation in the Netherlands.

Research on a selected sample of 800 Dutch companies falling under the target law reveals the dilemma:

[T] he percentage of female executive directors was 8.9 per cent, and of female non-executive directors 11.2 per cent. Furthermore, this study concluded that the majority of the annual reports did not provide the 'explanation' required by the 'comply or explain' principle, which is part of the target law. Sixty-two per cent of the companies that did not comply with the 30 per cent executive board target did not explain their non-compliance, while 57 per cent of the companies that did not comply with the nonexecutive board target did not provide an explanation. ${ }^{31}$

The underlying idea of the Dutch legislation is to ensure a balanced gender distribution on boards of public companies. Thus, companies not meeting this expectation must explain three things in their annual reports:

1) Why the seats are not evenly distributed;

2) How the company has tried to achieve a balanced distribution of the seats; and

\footnotetext{
${ }^{31}$ Mijntje Lückerath-Rovers, 'Gender Quota in the Boardroom: The Dutch Approach’ (2015) 20(1) Deakin Law Review 75, 92.
} 
3) How the company intends to realise a balanced distribution of the seats.

Professor Lückerath-Rovers also points to the advantages of more diversity on boards, including better gender diversity. She distinguishes between what she calls 'a business perspective', which translates to 'a business case', and 'a moral perspective', and summarises the business and moral arguments as to why women should not be excluded from or under-represented on boards.

Professor Lückerath-Rovers concludes by referring to an article by Nancy McKinstry, one of the two female CEOs in the Netherlands, that appeared in the Dutch Financial Times (7 October 2014) under the title, 'Getting Women to the Top Requires Effort from the Company Itself':

[L]et us not forget why diversity - of gender, but also nationality, experience, age, skills - is important for companies. To be able to choose the best man or woman for the job, you need access to the entire talent pool. Diversity also creates more perspectives in discussions, leading to better decision-making — which has direct influence on a company's results. ${ }^{32}$

\section{Australia}

1 Current State of Play and Potential to be Influenced by International Developments

Under the Workplace Gender Equality Act 2012 (Cth), departments, organisations and most larger companies must report annually on the number of their male and female employees and board members. In addition, since 2010 the Australian corporate governance code (the ASX Corporate Governance Council's Corporate Governance Principles and Recommendations) requires listed entities to report the proportion of women employees in the whole organisation, in senior executive positions and on the board. These provisions are currently in the process of being refined. However, no specific percentage of women on boards is mentioned.

In June 2010, the Australian Sex Discrimination Commissioner, Elizabeth Broderick, made the following recommendation:

[A] target of $40 \%$ representation of each gender on all publically [sic] listed Boards in Australia, to be achieved over five years, should be promoted. If

\footnotetext{
32 Nancy McKinstry, Editorial: CEO Nancy McKinstry Addresses Diversity at Wolters Kluwer (7 October 2014), quoted in Lückerath-Rovers, ibid 93.
} 
progress is not made, the Australian Government should consider legislating to require publicly listed companies and other large employers to achieve a mandatory gender diversity quota of a minimum of $40 \%$ of both genders within a specified timeframe, failing which penalties will be imposed. ${ }^{33}$

This target was not met by June 2015; it was reported that as of 31 July 2015 only 20.1 per cent of the seats in ASX200 listed companies were filled by women. ${ }^{34}$ The papers by Professor Michael Adams and Professor Peta Spender analyse the position in Australia and also provide international perspectives on the topic of gender and board diversity.

The reality in Australia and recent international developments in the EU regarding mandatory gender quotas, enforced through legislation, raise many questions. Perhaps the writing is on the wall and more and more countries will adopt legislation making it mandatory, at least for listed companies, to achieve a gender diversity quota of a minimum of 30-40 per cent of both genders on their boards within a specified timeframe.

\section{Some Practical Business Perspectives}

Three of the presenters at the Forum held on 20 October 2014 in Melbourne did not prepare written academic papers as they dealt with the topic of mandatory gender quota legislation from a practical point of view, drawing on their considerable business experience over many years.

Judith Fox (National Director, Policy \& Publishing, Governance Institute of Australia) presented a paper entitled 'Key Themes and Issues Regarding Board Diversity and Mandatory Gender Quota Legislation'. She pointed out that the increased focus in Australia on improving the representation of women at senior executive and board levels is based on research supporting the economic and business case for increased participation by women in senior roles. The perceived need for gender equality has seen reporting obligations introduced both through the ASX Corporate Governance Council's Corporate Governance Principles and Recommendations and legislation, with the aim of improving long-term performance and optimising the human capital available to an organisation.

\footnotetext{
${ }^{33}$ Elizabeth Broderick, Gender Equality Blueprint 2010 (23 June 2010) Australian Human Rights Commission $8<$ https://www.humanrights.gov.au/publications/gender-equality-blueprint2010>.

${ }^{34}$ See Australian Institute of Company Directors, Statistics <http://www.companydirectors.com. au/Director-Resource-Centre/Governance-and-Director-Issues/Board-Diversity/Statistics>.
} 
Fox also made the point that, without greater progress within organisations on adopting gender balance initiatives as measurable objectives, and without organisations being accountable to stakeholders for progress toward achieving those measurable objectives, the participation of women in senior roles is viewed as unlikely to increase. Disclosure obligations are intended to address this. Reporting is intended to assist entities to gather information so that they have a clearer understanding of gender balance within their organisations and what objectives they need to put in place to improve gender equality.

Fox explained that concerns had been expressed that reporting to date is inconsistent and speaks to intention more than action. The lack of comparable data also makes it difficult, both internally and externally, to assess progress. Entities seeking to improve participation and reporting can struggle to find guidance on strategies to increase gender balance at senior levels and to enhance the transparency of their disclosures.

Fox concluded that, unless measurable progress towards board gender diversity can be reported year-on-year in Australia, quotas set by the government and regulators may be viewed as a necessary next step. Yet there are strongly held views that the cultural shift that can take place within entities as they set their own targets and work toward achieving them can lead to more optimal outcomes than a compliance-based approach to meeting quotas.

The presentation by John Stanhope (Chair, Australia Post) had the to-the-point title of 'Mandatory Gender Quota Legislation Is Not the Way To Go'. He argued that diversity on boards starts with a diversity of views. He also argued that the danger of group-think is best dealt with by such diversity. The achievement of diversity on boards must be driven from the top, in particular by the chair of the board. In fact, he argued, legislation to mandate gender quotas may be considered offensive by those who are currently not well represented on company boards.

Peter Lamell (an experienced non-executive director who was drawing on a history of proven success as a CEO and member of over 25 Boards in the energy, power, resources, services and related sectors) presented under the following title: 'A Balancing Act: Issues and Concerns Regarding Board Diversity and Mandatory Gender Quota Legislation'. He discussed the importance of considering all forms of diversity, not just gender. This is particularly relevant in Australia where other diversity issues such as race, country of origin and religion are important, with over 50 per cent of the population either born overseas or with a parent born overseas. In Norway, by contrast, over 95 per cent of the population comes from the same ethnic background. Lamell proposed that the main focus on boards should be 
'diversity of thinking'. However, while it is important to have a holistic view of diversity in Australia, it is evident that any diversity is better than no diversity so it does make sense to have a strong, initial focus on gender diversity.

Setting criteria for selecting board members has now become a well-established process promoted by the AICD (Australian Institute of Company Directors). Lamell believes that these criteria should be extended to include elements of diversity and that this diversity should be used to demonstrate not just corporate strategy but key linkages to the stakeholders. It is critical, therefore, that boards have a structured approach to selection, which must incorporate diversity, and that they be vigilant to identify any elements of unconscious bias. Equally the chair and the nominations committee should themselves have a diverse membership and be fully committed to a robust process.

Whilst all organisations need to implement diversity and recognise its benefits, it is nevertheless important to focus on where the principle focus of action should be - the ASX 200 or wider. Lamell believes that there should be a strong focus on the ASX200 because these companies have the highest exposure and provide an excellent base for 'example setting'. However, with the increased reporting requirements imposed by the ASX and the Workplace Gender Equality Act, he argued that it is important that we take it on ourselves to measure, monitor, report on and challenge the performance of all listed and public unlisted companies. The performance of some government and government-linked boards has been encouraging. However, both they and we should be taking action to ensure that their outcomes are exemplary. Lamell also pointed out that not-for-profit boards provide an excellent opportunity for all the diverse elements of our population to gain board positions and the experience of being on boards.

Lamell also pointed out that resolving the challenge of diversity is a major issue for the Australia of today. We cannot afford to delay addressing this issue until people are already working in organisations, as their preconceptions about diversity have already become entrenched by this stage. Lamell believes that we must take a holistic approach to diversity and have education and activism at all stages in life - in the home, at school, in tertiary institutions, organisations, the workplace and, of course, on boards. Lamell also believes that the issue with board membership is strongly linked to the limited progress that women have made through organisations to the senior executive level. He concluded that there should be diversity at all levels in organisations so that we can create the board and executive pools of the future whilst recognising the importance and value of mentoring and leading by example. 


\section{AT A 'CRITICAL JUNCTURE' - MANDATORY BOARD GENDER LEGISLATION NOT INCONCEIVABLE}

The article by Professor Peta Spender argues convincingly in favour of mandatory gender quota legislation. It commences by giving a thorough overview of the background to the gender quota debate in Australia. It then puts the topic of quota legislation in context by examining the existing institutional arrangements in Australia that predict, or militate against, the introduction of board gender quotas. Following this, the article deals in detail with some contraindications for quotas in Australia: first, the perceived unfairness of affirmative action and the stigmatisation of beneficiaries and, second, the fact that quotas raise questions about the proportional regulation of the private sector.

The next part of her article deals with the justifications for mandatory gender quota legislation. After dealing with some 'functionalist justifications', including the assertion that 'women make a difference somehow', ${ }^{35}$ she encourages 'a healthy scepticism' regarding a business case for more women on boards. She argues as follows:

Most academics and commentators who write about corporate gender quotas seem to feel compelled to address the business case. However, some of the claims made under the business case are outlandish, implausible, essentialist or based on very small samples. Examples of some of the claims are that women are less likely to tolerate corporate crime, women on boards are more caring and women on boards are less likely to engage in tax avoidance. ${ }^{36}$

In addition, academics and commentators commonly reject the methodology of the business case:

The methodology of the business case remains problematic because of the challenges it poses to logical assessment, including the difficulty in finding a counterfactual scenario, or applying the difference-in-difference method, or deciding whether a correlation proves causality, or whether a reverse causality is in operation. The classic reverse causality problem is demonstrated by the ... ASX comment [quoted in her article] that corporations with women on their boards are stronger financial performers. The problem of determining causation lies in the fact that strong financial performers may encourage women to join their boards for all sorts of reasons,

\footnotetext{
${ }^{35}$ Peta Spender, 'Gender Quotas on Boards — Is It Time for Australia to Lean In?' (2015) 20(1) Deakin Law Review 95, 105.

${ }^{36}$ Ibid 106.
} 
so the causative factors may actually operate in reverse: rather than board diversity driving profitability, the latter encourages the former. ${ }^{37}$

Professor Spender notes that the importance of the business case is emphasised by some commentators, but that these commentators then remind women what huge responsibilities will come with more women serving on company boards in future. She points out that it can be 'dangerous' for women to be singled out because of their gender when the performance of a company is clearly multifaceted. Some statements referring to what will be expected of women in future as far as the business case is concerned typify, according to her, the problem with the business case:

[T]here is no certainty that women make a difference to business performance, yet it is on the basis of this justification that they are obliged to live up to our [men's] expectations and 'earn their stripes'. That is not a value that should be applied in this case. It is necessary therefore to examine more enduring justifications. ${ }^{38}$

Professor Spender then discusses the three justifications that are, in her view, 'enduring'. These are 'normative and include equality, parity and democratic legitimacy'. In her conclusion she again emphasises that change should be justified by enduring values such as parity, equality and democracy rather than misconceived functionalist arguments based upon the business case.

After discussing the 'enduring justifications', Professor Spender asks: 'Should we expect the introduction of a quota in Australia any time soon?'. She is clearly sceptical that this will happen soon. She points out that the introduction of a quota in Australia may to some extent depend on the progress of voluntary initiatives. However, a more fundamental question, she maintains, is whether Australia's political/policy bodies are amenable to diffusion, so that gender quota policy can flourish in Australia through importation from other jurisdictions. At the heart of her article is the concept of 'a critical juncture'. She points out that, generally, changes are more likely to occur at a critical juncture. This increased possibility of change, she explains, differentiates a critical juncture from a normal period of historical change. She then focuses on what can be expected at a critical juncture:

A critical juncture can bring about abrupt institutional change, as it presents leaders with an opportunity to enact new plans and realise new ideas by embedding them in established institutions. It is argued ... that we are at such a critical juncture now, first, because of the intense public interest in and

\footnotetext{
${ }^{37}$ Ibid.

${ }^{38}$ Ibid 107.
} 
commentary about this issue; and, second, because of the current salience of gender as a political issue. ${ }^{39}$

Professor Spender argues, with reference to the famous misogyny speech delivered by Julia Gillard and directed at the then Leader of the Opposition, Tony Abbott, in the House of Representatives on 10 October 2012, that ' $[\mathrm{t}]$ he reception of the speech transformed it from a political exchange into the makings of a critical juncture'. ${ }^{40}$ In addition, 'the intense public interest in gender as a political issue, ${ }^{41}$ is another reason why this critical juncture has been reached in Australia.

In the concluding parts of her article, she deals with the elements that must be considered when deciding a gender quota, and proposes a phased process of introducing mandatory gender quotas in Australia:

Phase 1 - a five-year period where voluntary initiatives and incentives are adopted to achieve a target of 40 per cent of each gender on ASX 200 boards.

Phase 2 - the imposition of a quota at the conclusion of a further five-year period enforced by sanctions for non-compliance. ${ }^{42}$

She reaches the following conclusions:

The time is ripe for Australia to legislate for mandatory gender quotas for corporate boards. Although Australian policy makers have favoured the use of voluntary initiatives to increase the participation of women on boards, progress is still too slow to satisfy the strong public appetite for change. ... Australian policy makers may be amenable to allowing the diffusion of gender quota policy from other jurisdictions that have successfully made the transition. In fact, they may welcome the change because the social debate has reached a critical juncture where gender has re-emerged as a salient political issue and there is a strong appetite for change which may influence political leaders. Legislation for board gender quotas for ASX 200 companies could be phased in, with clear timeframes which are contingent upon the failure of voluntary initiatives. ${ }^{43}$

\footnotetext{
${ }^{39}$ Ibid 113.

${ }^{40}$ Ibid 115.

${ }^{41}$ Ibid 96.

42 Ibid 118.

${ }^{43}$ Ibid 121.
} 
Finally she points out that the participation of women on boards is a measure of women's economic participation and democratic leadership:

The leadership that they provide is symbolic but has the potential to generate new and vital conceptions of citizenship and democracy. ${ }^{44}$

\section{South Africa: Aspirational LegisLation to ACHIEVE GENDER PARITY ON BOARDS}

In South Africa, the radical Women Empowerment and Gender Equality Bill was tabled in Parliament in November 2013. Under this Bill all organisations, corporations and government departments would have been required to have 50 per cent women on their decision-making bodies. The Bill was criticised widely, but irrespective of that it was passed by the National Assembly in March 2014. However, as will be seen from the article by Janine Hills, the legislation has been referred back to the Parliament for further consultation. Nevertheless, the message is clear, namely that it is likely that gender quotas will become law in South Africa in future.

Hills's paper deals with women's empowerment and gender equality legislation, as well as the Black Economic Empowerment (BEE) Program, in South Africa. Hills points out that the South African BEE Scorecard Policies and Empowerment Strategies are unique. They affect quota decisions and behaviour, and also provide a unique statutory way of encouraging race diversity at all levels of organisations in South Africa. She provides several arguments why gender diversity matters at board level. She also explains the central role of boards in the corporate decision making process, continuing as follows:

Good corporate decision-making thus requires the ability to hear and consider different points of view, which come from people who have different backgrounds, cultures, experiences, and perspectives. Companies that have women directors and executives lead by example. They send a clear message that they value diversity of thought and experience. While the advantages and disadvantages of each approach are open to debate, the general consensus is that appointing more women to positions of leadership and boards is smart business, is good for business, and is a proactive image and reputation

${ }^{44}$ Ibid. 
builder. Whether or not to appoint women to board level is a business issue, and not a women's issue. ${ }^{45}$

Hills's article also deals with the history of women's participation in South Africa. An interesting aspect of her discussion focuses on the factors that are holding South African women back in general. They include, inter alia, lack of education, harmful domestic and cultural practices, the high unemployment rate, the disparity between types of employment for men and women and the limited pool of women that possess the required skills. Hills makes out a strong case for why women are integral to corporate and government leadership, and then deals in detail with South Africa's National Policy Framework for women's empowerment and gender equality and the Broad-Based Black Economic Empowerment (B-BBEE) and general gender transformation initiatives in South Africa.

Hills also deals with the factors preventing women in business in South Africa from advancing to board level. Although she argues that it is likely that gender quotas will become law in South Africa in the foreseeable future, she has some reservations about whether the proposed legislation contained in the Women Empowerment and Gender Equality Bill adopts a realistic approach. She asks what guarantees there are that the Bill will be effectively monitored. One of the final parts of her article focuses on the current quota statistics in South Africa. She points out that South Africa fares quite well in the light of international statistics. South Africa is one of the top 20 countries as measured by the World Economic Forum's Global Gender Gap Report that demonstrates increasing equality between men and women. South Africa was ranked $12^{\text {th }}$ in the world by the said report in 2010 and $6^{\text {th }}$ in 2009 .

Hills's argument of a business case for women is not limited to financial performance. She also argues that appointing more women has a positive impact on reputational transformation, and can lead to increased productivity and a higher retention rate of employees. She also mentions a trend in recent times that a more diverse board, having a good gender balance, is seen in a positive light by investors and thus draw investors. The final part of her article deals with several means by which South Africa could eventually reach a 50 per cent gender quota at board level. She concludes on a positive note, but is realistic in pointing out that there is still a lot to be done before it would be possible to say unreservedly that there is gender equality in South Africa:

\footnotetext{
45 Janine Hills, 'Addressing Gender Quotas in South Africa: Women Empowerment and Gender Equality Legislation’ (2015) 20(1) Deakin Law Review 153, 156.
} 
What has been evident is that South Africa has made progress in terms of women's empowerment and the reduction of discrimination towards women in the workplace. However, this has only been the beginning of a far longer journey, particularly with regard to the progress that is still to be made in the private sector. ${ }^{46}$

\section{OVerall Themes AND Issues}

There is no doubt that the mandatory gender quota legislation in Norway sparked a lot of interest in similar legislation in the rest of the world. Several countries have followed Norway's example, but the percentage of women directors required, and also the sanctions if the quotas are not met, vary from country to country. Germany is the country that has most recently adopted mandatory board gender legislation, requiring 30 per cent of supervisory boards to consist of women. This development is significant, because the intention to ensure that up to 40 per cent of the boards of larger companies in the EU should consist of women was road-blocked (at least for the time being) when the European Council could not reach agreement on a directive promoting this goal. It means that all eyes will probably be on Germany, especially because of the size of its economy, to see how this new approach is received there. It was, however, pointed out that a constitutional challenge against the German legislation is possible.

The following things stand out from the discussions at the Forum and the articles contained in this special issue of the Deakin Law Review:

1. There is no consensus regarding whether appointing 30-40 per cent of women to boards makes, or will make, a difference in board performance. Further, what was meant by 'performance' was not defined narrowly by any of the papers. However, there was consensus that having women on boards is important, and several arguments, some more convincing than others, were presented as to why it is important to have more women on boards: It breaks the 'old boys club'; it prevents 'group-think'; it improves board decision-making processes; female directors are more benevolent; female directors are more universally concerned; female directors are less power-orientated than men; having more women on boards increases board effectiveness through reducing the level of conflict and ensuring a high quality of board development activities, and so forth.

\footnotetext{
${ }^{46}$ Ibid 183-4.
} 
2. There is no consensus that mandatory gender quota legislation is the right way to go;

3. There was, however, agreement by several of the participants at the Forum and several of the presenters that if more women are not appointed to boards in countries currently without mandatory board gender legislation, such legislation will be considered seriously by governments and policy makers;

4. Professor Spender's article defends the case for mandatory gender quota legislation more strongly than any of the other articles or presentations at the Forum. Her underlying logic and justifications for mandatory gender quota legislation are most convincing. Her prediction that Australia has reached a 'critical juncture' as far as the issue of mandatory gender quota legislation is concerned is based on strong indicators.

5. There is general consensus that board diversity is important and that there are many advantages associated with board diversity. Again a wide variety of arguments were provided as to why this is the case and, again, some were more convincing than others. An answer to the question, 'What measures should be applied to ensure a board with the "right diversity”?' remains elusive, however.

6. The 'business case' for appointing more women to boards has as many supporters as sceptics and it is perhaps sensible, for the moment, to move on by simply saying that the 'business case' is no longer the central justification for either appointing more women to boards or justifying mandatory gender quota legislation. There are enough other very good arguments for appointing more women to boards, including women's potential contributions to 'the purpose of the corporation'. Nowadays it is accepted that corporations should not only strive for 'profit maximisation', but that part of their 'purpose' is to ensure longterm sustainable growth for the corporations themselves and also to act in the public good. ${ }^{47}$

\footnotetext{
${ }^{47}$ See Jean J du Plessis and Andreas Rühmkorf, above n 8, 54.
} 